\title{
Intact Epidermal Cell Assay for Ornithine Decarboxylase Activity
}

Diane I. Roseeuw ${ }^{1}$, Elizabeth A. Duell ${ }^{2}$, and Cynthia L. Marcelo ${ }^{2}$

1. Department of Dermatology, Adjunkt-Kliniekhoofd, Vrye Universiteit Brussel, AZ-VUB, Laarbeeklaan 101, B-1090 Brussels, Belgium

2 Department of Dermatology, University of Michigan Medical School, Ann Arbor, MI 48109, USA

Summary. A procedure measuring the ornithine decarboxylase (ODC) activity and polyamine formation of intact neonatal mouse epidermal cells in culture has been developed and tested. Basal cells prepared from neonatal mouse epidermis were plated on round 15-mm Lux coverslips, placed in Costar 24 well culture clusters and grown at $32{ }^{\circ} \mathrm{C}$ in $\mathrm{M}-199+13 \%$ fetal bovine serum. Before assay the cells were rendered permeable to ornithine ${ }^{14} \mathrm{C}$ and $\mathrm{ODC}$ inhibitors using the buffer described by Berger et al. [3]. The slides, covered with adhering cell layers, were then placed in vials, covered with assay buffer and assayed intact for ODC activity. The ODC reaction was terminated by addition of citric acid to the buffer and the amount of ${ }^{14} \mathrm{CO}_{2}$ released was determined by scintillation counting of a center well filled with trapping agent. The baseline ODC activity of the intact cells was $500-1,000 \mathrm{pmol}^{14} \mathrm{CO}_{2} / \mathrm{mg}$ protein $/ 45 \mathrm{~min}$. The validity of this ODC assay procedure using intact neonatal mouse keratinocytes was tested by use of three specific ODC inhibitors and by measuring the formation of polyamines from uniform labeled ornithine. The results indicated that authentic ODC activity was measured and preserved in this intact neonatal mouse epidermal cell assay. This technique holds promise for future studies of epidermal cell regulation of ODC and polyamine synthesis and studies of the multiple ornithine metabolites and conjugates formed, using a highly manipulable in vitro system.

Key words: Primary keratinocytes - Intact epidermal cell ODC activity Polyamine metabolites and conjugates - Epidermal cell culture

\section{Introduction}

In the epidermal cell, as in all other tissues, ornithine decarboxylase (ODC) (Lornithine carboxylyase; EC 4.1.1.17) is the first and, most probably, the ratelimiting enzyme in polyamine biosynthesis $[17,19]$. This unique and ubiquitous enzyme may have an important function in the regulation of epidermal cell division

Offprint requests to: Diane I. Roseeuw, MD (address see above) 
and growth and in epidermal tumor promotion $[9,12,15,24,25,27]$. Besides the evidence implicating ODC and polyamines in animal model epidermal hyperproliferation and hyperplasia, the intracellular levels of the polyamines and the activity of their biosynthetic enzymes [22] may have significant correlation with the accelerated epidermal proliferation of the psoriatic epidermis $[5,26]$. There is at present, however, no evidence demonstrating a direct cause and effect mode of regulation between polyamine biosynthesis (ODC induction) and initiation of epidermal cell proliferation.

The enzyme ODC is unique in a number of ways: (a) it has a biologic half-life of $10-20 \mathrm{~min}$ [21], which can vary depending on growth conditions [8]; (b) the induction of ODC is controlled by the production of a protein(s) that is an ODC inhibitor (ODC-antizymes) [7]; (c) the synthesis of the ODC-antizyme(s) is induced by the polyamines putrescine, spermidine, or spermine [7], i.e., there is a negativefeedback regulation of ODC by its endproducts; (d) there are two or more enzymatic forms of ODC [13]; and (e) moreover, ODC is an enzyme that can exhibit changes in its biologic half-life [4].

The usual method of assay for ODC activity is the measurement of ${ }^{14} \mathrm{CO}_{2}$ release from $\mathrm{L}-\left(1-{ }^{14} \mathrm{C}\right)$ ornithine by the ODC present in the supernatant fraction of homogenized tissue or cells $[17,19]$. The ODC present in the supernatant of homogenized isolated epidermal cells is difficult to assay because of the short halflife of the enzyme [21] and because the control level of ODC in epidermal cells is so low that often the activity is below assay sensitivity.

To overcome these problems, i.e., the complex control of an indicible enzyme with multiple forms, a variable, short half-life, and low control level activity, we designed and tested the first ODC assay using intact living epidermal cell cultures $[11,20]$. With the whole-cell enzyme assay we can better approximate the physiologic conditions of intact epidermis, i.e., feedback regulation, synthesis of ODC enzyme(s) and ODC-antizymes, and functional changes in ODC half-life during the assay itself instead of assaying a degrading enzyme in the absence of possibly essential control mechanisms. The complete details of this whole-cell technique are described in this report.

\section{Material and Method}

\section{Reagents}

Neonatal mice were obtained from the Dermatology Department (University of Michigan Medical School) BALB/c colony. Medium 199 (M-199, modified with Earle's salt, with glutamine, without sodium bicarbonate) and fetal bovine serum (FBS) were purchased from Flow Laboratories, Rockville, MD, USA. Penicillin and streptomycin (P\&S), phosphate buffered saline (PBS, Dulbecco's) were from Flow Laboratories, McLean, VA, USA. Dansyl hydrochloride was obtained from Sigma Chemical Co. (St. Louis, MO, USA). L- $\left[1-{ }^{14} \mathrm{C}\right]$ ornithine, $\mathrm{L}-\left[{ }^{14} \mathrm{C}(\mathrm{U})\right]$ ornithine, and $\left[1-{ }^{14} \mathrm{C}\right] \alpha$-ketoglutaric acid, sodium salt were obtained from New England Nuclear (Boston, MA, USA). The respective specific activities were: $49.2 \mathrm{mCi} / \mathrm{mmol}, 247 \mathrm{mCi} / \mathrm{mmol}$, and $53.6 \mathrm{mCi} / \mathrm{mmol}$. Putrescine dihydrochloride $\left[1,4{ }^{14} \mathrm{C}\right](\mathrm{Pu})$ $(116 \mathrm{mCi} / \mathrm{mmol}),\left[{ }^{14} \mathrm{C}\right]$ spermidine trihydrochloride $(\mathrm{spd})(120 \mathrm{mCi} / \mathrm{mmol}),\left[{ }^{14} \mathrm{C}\right]$ spermine tetrahydrochloride (spm) $(120 \mathrm{mCi} / \mathrm{mmol})$, and the aqueous (ACS) and organic (OCS) counting scintillation fluid were purchased from Amersham, Arlington Heights, IL, USA. Dowex $50\left\lceil\mathrm{H}^{+}\right]$form was from Bio-Rad, Richmond, CA, USA. The Lux plastic coverslips were from Flow Laboratories, Newbury Park, CA, USA, and tissue cuiture cluster 24 from Costax, Cambridge, MA, USA. The center wells and rubber 
stoppers for the ODC assay were purchased from Kontes, Vineland, NJ, USA. Thin layer chromatography (TLC) plates were purchased from Analtech, Newark, DE, USA.

\section{Epidermal Cell Cultures}

The primary neonatal mouse keratinocyte cultures were prepared as described by Marcelo et al. [11]. Cells were plated in Costar 24 well culture clusters containing $15-\mathrm{mm}$ round Lux coverslips in each well and grown in $5 \% \mathrm{CO}_{2}$ in air gassing at $32^{\circ} \mathrm{C}$ in Medium-199, containing $50 \mathrm{IU} / \mathrm{ml}$ of penicillin and $50 \mu \mathrm{g} / \mathrm{ml}$ of streptomycin plus $13 \%$ FBS. Four hours after plating, the cells were washed with cold Dulbecco's PBS to remove all nonadherent keratinocytes as described by Lichti et al. [9].

\section{Ornithine Decarboxylase Assay}

The coverslips with intact adherent cell monolayers were rinsed twice with cold Dulbecco's PBS. All subsequent procedures were carried out at $4^{\circ} \mathrm{C}$ unless otherwise indicated. The cells were rendered permeable to $\mathrm{L}-\left[{ }^{14} \mathrm{C}\right]$ ornithine using a permeable buffer (Tris $10 \mathrm{mM}$, sucrose $250 \mathrm{mM}$, EDTA $1 \mathrm{mM}$, $\mathrm{MgCl}_{2} 4 \mathrm{mM}$, and 2-mercapto-ethanol $30 \mathrm{mM}$ ) [3]. The coverslips with the cells were placed in vials and covered with $475 \mu \mathrm{l}$ of ice-cold $50 \mathrm{mM}$ sodium potassium phosphate buffer $\mathrm{pH} 7.2$, dithiothreitol $(1 \mathrm{mM})$, EDTA $(0.1 \mathrm{mM})$, pyridoxal $\mathrm{PO}_{4}(0.4 \mathrm{mM})$, and $0.9 \% \mathrm{NaCl}$. Cell layers on coverslips were fixed with absolute ethanol for $15 \mathrm{~min}$ and used as blanks for the assay. To the vials, $25 \mu \mathrm{l}$ ornithine $(1.25 \mu \mathrm{Ci})$, $\left.63 \mu \mathrm{l} \mathrm{L}-{ }^{14} \mathrm{C}(\mathrm{U})\right]$ ornithine $(1.25 \mu \mathrm{Ci})$, or $1.25 \mu \mathrm{Ci}\left[1,4{ }^{14} \mathrm{C}\right] \mathrm{Pu}$ was added. The final concentration in the reaction mixture was $56.0 \mu \mathrm{M}$ for $\mathrm{L}-\left[1{ }^{14} \mathrm{C}\right]$ ornithine $[27], 10 \mu \mathrm{M}$ for $\mathrm{L}-\left[{ }^{14} \mathrm{C}(\mathrm{U})\right]$ ornithine, or $53 \mu \mathrm{M}$ for ${ }^{14} \mathrm{C}$ putrescine. The vials were capped with serum stoppers containing plastic center wells filled with $0.2 \mathrm{ml} \mathrm{CO}_{2}$ trapping agent (1 part 2-methoxy-ethanol, 2 parts 2-aminoethanol) and immediately placed in a $37^{\circ} \mathrm{C}$ shaking waterbath. After 45 or $60 \mathrm{~min}, 0.5 \mathrm{ml} 1 \mathrm{M}$ citric acid was added to the vials. These were left in the shaking bath for another $30 \mathrm{~min}$. The center wells containing the trapped ${ }^{14} \mathrm{CO}_{2}$ were put in $10 \mathrm{ml}$ ACS and counted in a Packard Tri-Carb Scintillation counter (Packard Instrument Co. Inc., Downers Grove, IL, USA). To the coverslips (epidermal cells) and reaction mixture in the vials was

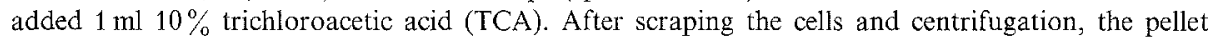
containing cellular DNA, RNA, and proteins was resuspended in $1 \mathrm{~N} \mathrm{NaOH}$ and assayed for protein by the Lowry method as previously described [11] or was resuspended in $3 \%$ perchloric acid (PCA) and hydrolyzed to determine the DNA content using the Burton method [11]. The TCA supernatant was saved for polyamine qualitative analysis.

\section{Determination of Polyamine Biosynthesis}

The TCA supernatants were applied to a $9 \times 40 \mathrm{~mm}$ Dowex $50\left[\mathrm{H}^{+}\right]$column. The column was washed with eight 5-ml fractions of sodium phosphate buffer (pH 8.0) and two 5-ml fractions of $1 \mathrm{~N} \mathrm{HCl}$. The polyamines were eluted from the resin with three $5-\mathrm{ml}$ fractions of $6 \mathrm{~N} \mathrm{HCl}$. A neutralized $0.5 \mathrm{ml}$ aliquot of each 6-N HCL fraction was counted to locate the labeled polyamines. The first 6- $\mathrm{N} \mathrm{HCl}$ fraction, containing most of the ${ }^{14} \mathrm{C}$-polyamines, was evaporated to dryness in a $60^{\circ} \mathrm{C}$ waterbath with a stream of air prior to dansylation. A number of samples were hydrolyzed for $16 \mathrm{~h}$ at $70^{\circ} \mathrm{C}$ to convert the polyamines to the nonderivitized forms prior to evaporation. The polyamine samples were dansylated using standard procedures [23]. To each sample was added $20 \mu \mathrm{l}$, containing $20 \mu \mathrm{g}$ putrescine, spermidine, and spermine and $100 \mu \mathrm{l}$ diluted dansly chloride $(30 \mathrm{mg} / \mathrm{ml}$ acetone). The dansylated polyamines were extracted into $100 \mu \mathrm{l}$ benzene by vortexing the samples. The polyamines were separated by thin-layer chromatography (TLC). Silica gel G plates were spotted with $40 \mu \mathrm{l}$ of the benzene-extracted dansylated polyamines. The chromatograms were developed in two dimensions. The first solvent system containing cyclohexane - ethylacetate $(1: 1, \mathrm{v} / \mathrm{v})$; the second solvent system consisted of chloroform triethylamine $(50: 6, \mathrm{v} / \mathrm{v})$. The areas containing dansylated polyamines were located by fluorescence under UV light. The polyamines were scraped from the plates and eluted from the silica gel by adding $3 \mathrm{ml}$ benzene, triethylamine (95:5), and vortexing vigorously. The benzene and triethylamine were removed by evaporation under a stream of air and the residue was counted in $10 \mathrm{ml} O C S$ to determine the ${ }^{14} \mathrm{C}$ content of each polyamine. One set of the evaporated $6-\mathrm{N} \mathrm{HCl}$ fraction, containing the ${ }^{14} \mathrm{C}$ polyamines was sent to Dr. Abdel-Monem at the University of Minnesota for confirmation of our results. Standard procedure for dansylation and TLC of polyamines was done [2]. 
Determination of $\alpha$-Ketoglutarate Decarboxylase Activity

$\alpha$-Ketoglutarate decarboxylase activity in the pellet and supernatant fractions of sonicated cells was assayed using $\left[1-{ }^{14} \mathrm{C}\right] \alpha$-ketoglutarate sodium salt as substrate; the final concentration was $0.4 \mathrm{mM}$ containing $0.5 \mu \mathrm{Ci}$.

\section{Results}

\section{The Keratinocyte Cultures}

In Fig. 1 is presented a phase-contrast light micrograph and a transmission electron micrograph of the primary keratinocyte cultures used in this study. Figure $1 \mathrm{~A}$ is a
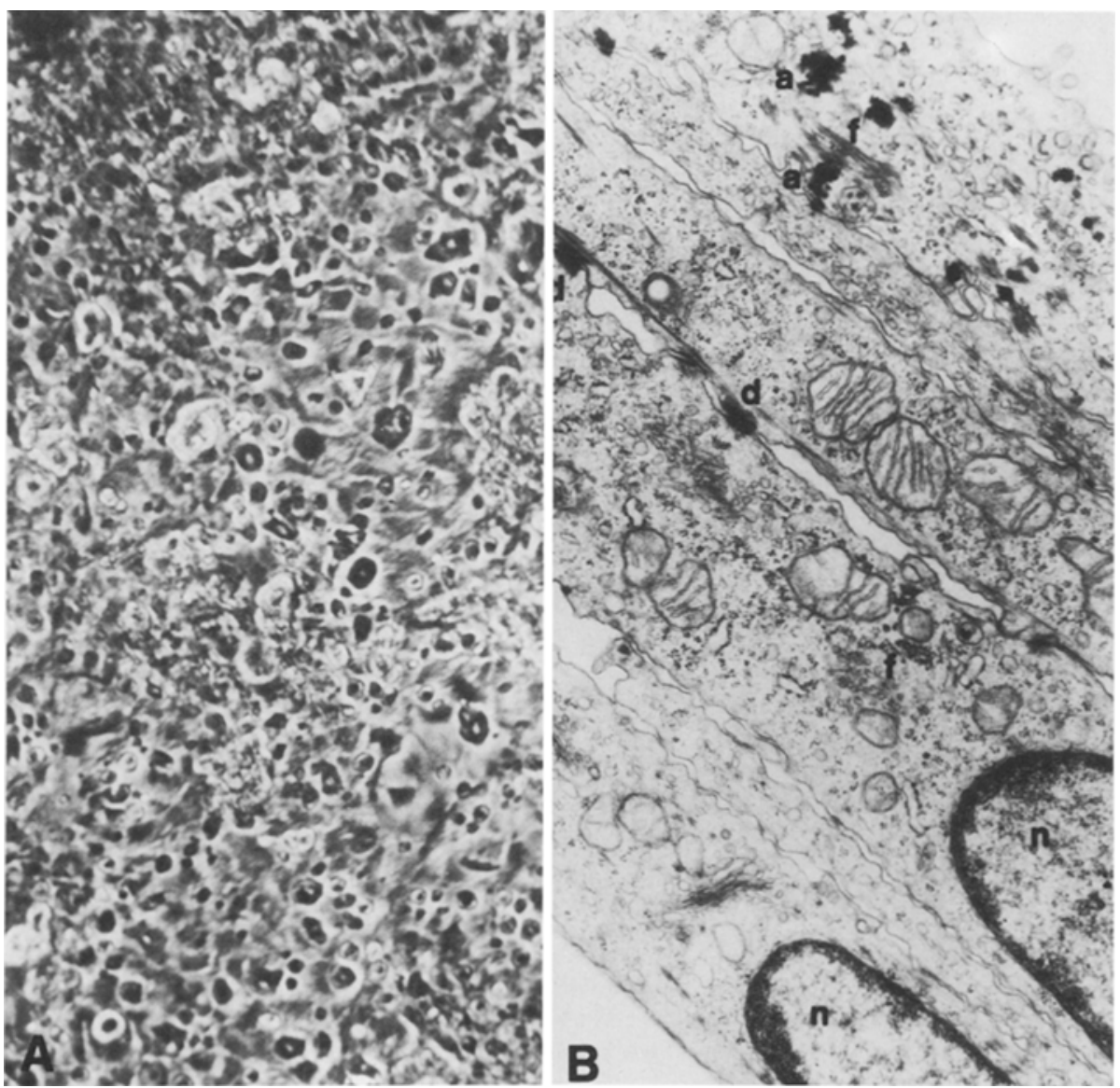

Fig. 1A, B. Phase-contrast light micrograph and transmission electron micrograph. A Phase-contrast light micrograph of day-4 primary neonatal epidermal cell culture in M-199 with $13 \%$ FBS and penicillin and streptomycin. The multilayered nature of the cultures give the phase-contrast micrographs an unusual appearance. $\times 200$. B Transmission electron micrograph of day- 6 keratinocyte culture showing cell layers. The bottom and third cell layers have a nucleus $(n)$, Desmosomal complexes $(d)$ can be seen between the third and fourth cell layers and fibrils $(f)$ and dense amorphous aggregates $(a)$ are present in the upper cell layers. $\times 5,018$ 
phase-contrast light micrograph of a culture 4 days after plating and shows the multilayered and specialized state of the cultures. The cultures, originating as a basal cell in monolayer, undergo a growth pattern in which proliferation, stratification, and differentiation occur concomitantly. The proliferation of these primary keratinocyte cultures demonstrated an oscillating semisynchronous pattern over a 3-4-week period and have neither a plateau nor a logarithmic growthphase [11]. In an autoradiographic study, only $10 \%-30 \%$ of the cells proliferated over any 20 -h period within the first 3 weeks of culture [11]. As the cultures proliferate and stratify, differentiated cells are shed into the medium [11]. The electron micrograph in Fig. 1B better depicts the extent of stratification and differentiation: the desmosomes, fibers, and electron-dense amorphous aggregates are characteristic of the epidermal keratinocytes of the skin.

\section{ODC Activity of Primary Keratinocyte Cultures}

Comparison of Various Preparations. One-day-old primary epidermal cell cultures were assayed for baseline ODC activity using different procedures (Table 1). In one procedure, the cells were scraped from six coverslips, homogenized in the ODC assay buffer, and centrifuged at $500 \times g$. The pellet and supernatant were then each assayed for ODC or $\alpha$-ketoglutarate decarboxylase activity. In the second procedure, the cultures remained intact on the coverslips and were used in the ODC assay with, and without, exposure to the permeable buffer. The cultures were exposed to this permeable buffer to facilitate the entry of ODC inhibitors and other drugs into the cells. Our studies (data not presented) showed that there was no difference in ODC activity between the permeable-buffer-treated and nontreated cells, although the values for ODC activity in the cells exposed to the permeable buffer showed less variance.

The ODC activity of homogenized cells is much lower than the activity of the intact cells (Table 1 ). The posibility that ${ }^{14} \mathrm{C}$-ornithine was being shunted into the Krebs cycle [14], thus releasing ${ }^{14} \mathrm{CO}_{2}$ from reactions other than ODC activity, was tested. We assayed the pellet from the homogenized epidermal cells to determine the degree of ${ }^{14} \mathrm{C}$-ornithine decarboxylation activity of the membrane fractions of the cells; ODC is a cytoplasmic enzyme. The results, as presented in Table 1, show

Table 1. Comparison of ODC aetivity in intact and fractionated epidermal cells, and the integrity of the Krebs cycle in the pellet of fractionated cells

\begin{tabular}{|c|c|c|c|c|}
\hline \multirow[t]{2}{*}{ Substrate } & \multicolumn{2}{|c|}{ Homogenates } & \multicolumn{2}{|c|}{ Whole cells } \\
\hline & Pellet & Supernatant & $(+)$ Buffer & $(-)$ Buffer \\
\hline $\begin{array}{l}\mathrm{L}-\left(1-{ }^{14} \mathrm{C}\right) \text { ornithine } \\
\alpha-\left(1-{ }^{14} \mathrm{C}\right) \text { ketoglutarate }\end{array}$ & $\begin{array}{r}3.30 \\
6,643.61\end{array}$ & $\begin{array}{r}15.75 \\
225.19\end{array}$ & $\begin{array}{l}564 \pm 6.9 \\
N=4\end{array}$ & $\begin{array}{l}730 \pm 267.7 \\
N=2\end{array}$ \\
\hline
\end{tabular}

Day- 1 cultures on coverslips were assayed for ODC activity with $(+)$ and without $(-)$ exposing the intact cells to permeable buffer

$\mathrm{ODC}$ activity $=$ mean $\pm \mathrm{SEM}$ in pmol ${ }^{14} \mathrm{CO}_{2} / \mathrm{mg}$ protein $/ 45 \mathrm{~min}$

$\alpha$-Ketoglutarate decarboxylase activity is in $\mathrm{pmol}^{14} \mathrm{CO}_{2} / \mathrm{mg}$ protein $/ 45 \mathrm{~min}$ 

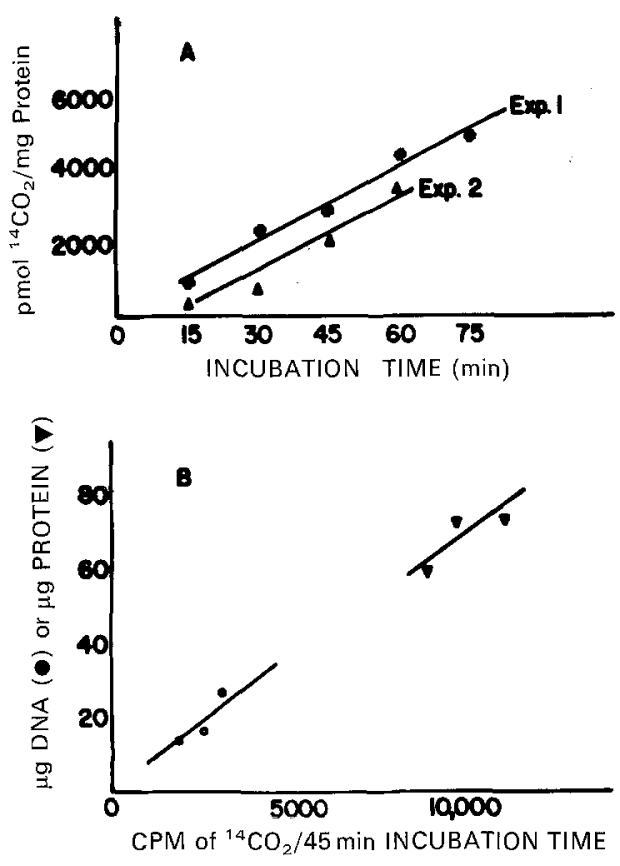

Fig. 2A, B. Linearity of ODC activity. A With time, each assay was done in duplicate. B With the amount of protein $\mathbf{\nabla}$, with the amount of DNA $11^{14} \mathrm{C}$-ornithine or ${ }^{14} \mathrm{C}(\mathrm{U})$ ornithine was used as substrate

negligable decarboxylation of ${ }^{14} \mathrm{C}$-ornithine although, significantly, decarboxylation of the Krebs cycle substrate $\alpha-\left[1-{ }^{14} \mathrm{C}\right]$ glutarate occurred, indicating a viable cell pellet.

In the intact cell assay, if $1,4{ }^{14} \mathrm{C}$ putrescine was used as substrate instead of labeled ornithine no release of ${ }^{14} \mathrm{CO}_{2}$ occurred. This indicated that diamine oxidase activity and subsequent decarboxylation reactions exhibit minimal activity in these assay conditions.

Linearity of the $O D C$ Activity. The ODC activity of 1-day-old cultures was determined. The assay was stopped $15,30,45,60$, and 75 min after initiation. As seen in Fig. 2, the ODC activity of intact living cells is linear with time for at least $60 \mathrm{~min}$ and is linear with respect to protein or DNA concentrations.

\section{Inhibition of ODC Activity of Whole Epidermal Cells}

The specificity of the ODC assay of living whole cells was tested by addition of three specific inhibitors of ODC activity. $\alpha$-Methyl ornithine ( $\alpha \mathrm{Me}-\mathrm{O})$ and $\alpha$-hydrazino ornithine $(\alpha \mathrm{HO})$ are known potent competitive inhibitors of ODC activity $[1,6]$, whereas L.D- $\alpha$-difluoromethyl ornithine ( $\alpha$ DFMO) is an irreversible inhibitor of ODC [10]. The data presented in Table 2 indicate that all three inhibitors at $0.5-5 \mathrm{mM}$ concentrations decreased the ODC activity from $40 \%$ to $80 \%$. At the higher concentrations, these three substances may also inhibit a variety of other decarboxylases [6]. 
Table 2. Inhibition of ODC activity

\begin{tabular}{llll} 
Control & $\alpha$-Methyl-ornithine & $\alpha$-Hydrazino ornithine & $\begin{array}{l}\alpha \text {-Difluoro methyl } \\
\text { ornithine } \\
\left(1-5 \times 10^{-3} \mathrm{M}\right)\end{array}$ \\
\hline $100 \%$ & $\begin{array}{l}\left(1-5 \times 10^{-3} \mathrm{M}\right) \\
\mathrm{N}=7\end{array}$ & $\begin{array}{l}\left(0.5-5 \times 10^{-3} \mathrm{M}\right) \\
N=6\end{array}$ & $\begin{array}{l}59 \% \pm 17.55 \% \\
N=2\end{array}$ \\
\hline
\end{tabular}

Values are in percent control

Four hours after plating the cultures were rinsed with cold Dulbecco's PBS

The inhibitors were added to the medium $14 \mathrm{~h}$ prior to ODC assay; the same concentrations were added to the permeable buffer and the ODC assay buffer

ODC activity was measured on day 1 of culture

Fig. 3. Elution of Dowex $50\left(\mathrm{H}^{+}\right)$column of the reaction substrate and products from cells assayed with $1-{ }^{14} \mathrm{C}$-ornithine, ${ }^{14} \mathrm{C}(\mathrm{U})$ ornithine, and $1,4{ }^{14} \mathrm{C}$ putrescine. Labeled ornithine is eluted in the sodium phosphate buffer, while labeled putrescine, polyamines, and polyamine-like compounds are eluted in the $6-\mathrm{N} \mathrm{HCl}$ fraction

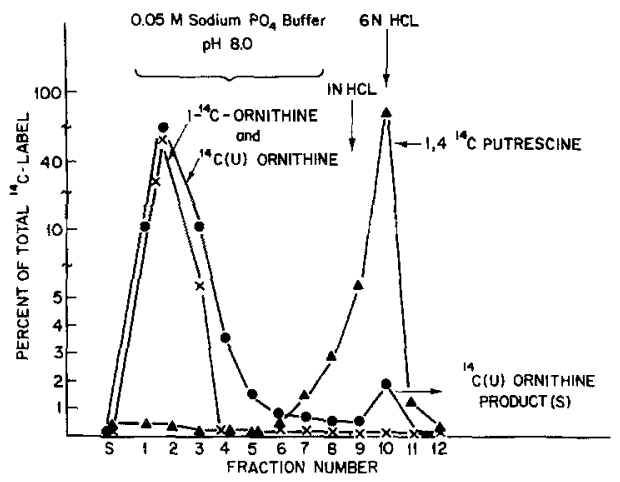

\section{Evaluation of Products of $O D C$ Activity in Whole-Cell Cultures}

Column Chromatography. When $1{ }^{14} \mathrm{C}$-ornithine is used as a substrate for ODC, the products are ${ }^{14} \mathrm{CO}_{2}$ and unlabeled putrescine and other polyamines. Use of ${ }^{14} \mathrm{C}(\mathrm{U})$ ornithine as a substrate yields ${ }^{14} \mathrm{CO}_{2}$ - and ${ }^{14} \mathrm{C}(\mathrm{U})$-labeled putrescine and other labeled polyamines. The ${ }^{14} \mathrm{C}$ content of the fractions obtained by Dowex 50 $\left(\mathrm{H}^{+}\right)$column chromatography of the incubation mixture $\left[1-{ }^{14} \mathrm{C}\right.$-ornithine, ${ }^{14} \mathrm{C}$ (U)-ornithine, or $1,4{ }^{14} \mathrm{C}$ putrescine as substrate] following termination of the whole-cell assay with citric acid is presented in Fig. 3. Hydrolysis of the samples prior to chromatography did not change the results.

With $1{ }^{14} \mathrm{C}$-ornithine as substrate, $0.18 \%$ of the total counts were released as ${ }^{14} \mathrm{CO}_{2}$. Chromatography of the incubation mixture showed that $99 \%$ of the added counts were eluted in the sodium phosphate buffer fractions which contain the unreacted $1-{ }^{14} \mathrm{C}$-ornithine. The polyamines formed with $1-{ }^{14} \mathrm{C}$-ornithine as the substrate were unlabeled, and, therefore, there were few or no counts present in the fractions eluted with $6 \mathrm{~N} \mathrm{HCl}$.

When ${ }^{14} \mathrm{C}(\mathrm{U})$ ornithine was used as a substrate, ${ }^{14} \mathrm{C}$ labeled products were found in the $6 \mathrm{~N} \mathrm{HCl}$ and $88 \%$ of the total counts were eluted by the phosphate buffer (unreacted ${ }^{14} \mathrm{C}$-ornithine). When $1,4{ }^{14} \mathrm{C}$ putrescine was used as substrate, most of the radioactivity was eluted with $6 \mathrm{~N} \mathrm{HCl}$. These results indicate that intact 


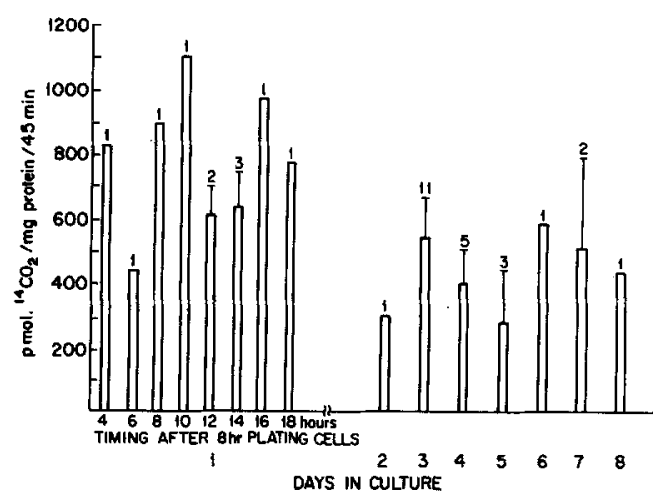

Fig. 4. Baseline ODC activity of primary neonatal mouse epidermal cells in culture from day 1 to day 8 of culture is from 500 to $1,000 \mathrm{pmol} / \mathrm{mg}$ protein $/ 45 \mathrm{~min}$. Differences in baseline ODC activity between day-1 and day-2-8 cells in culture probably reflected slight variations in dissociation procedures (i.e., slightly older mice, batch differences in trypsin activity or in fetal bovine serum, etc.). In one experiment, there was no more than $10 \%$ variation between triplicate or quadruplicate control and treated cells

living cells convert ornithine to polyamines or polyamine-like compounds as ascertained by fractionation of the incubated materials by Dowex 50 column chromatography.

Thin Layer Chromatography. Doctor Abdel-Monem analyzed the contents of the 6- $\mathrm{N} \mathrm{HCl}$ fractions of the chromatographed samples for the presence of polyamines after dansylation of the fraction. It was found that $60 \%$ of the radioactivity in this fraction was extractable into toluene as dansylated polyamines. The other $40 \%$ of the counts remained in the aqueous fraction and the identity of these polyaminelike compounds is uncertain. The extractable radioactive compounds, when separated on silica gel $G$ or alumina TLC plates, had the same mobility as dansyl putrescine. No radioactivity was detected in the areas corresponding to spermidine, spermine, $\mathrm{N}^{1}$-acetyl spermidine, or $\mathrm{N}^{8}$-acetyl spermidine.

Thus, the whole epidermal cells synthesize polyamines and polyamine-like compounds that are eluted from Dowex 50 columns with $6 \mathrm{~N} \mathrm{HCl}$. One such polyamine is probably putrescine, although other as yet unidentified compounds with properties similar to polyamines are also synthesized. The ratio of ${ }^{14} \mathrm{CO}_{2}$ to ${ }^{14} \mathrm{C}$ in the polyamine fraction was equal to or less than 1.0 (data not presented).

\section{Constancy of the ODC Activity in Whole Keratinocyte Cultures}

The ODC activity of primary epidermal cell cultures was determined over a daytime period after plating in 35 separate experiments. On the first day after plating, the activity was slightly higher (about a $50 \%$ increase) than on subsequent days. The data given in Fig. 4 show that the baseline activity of ODC ranged from 500 to $1,000 \mathrm{pmol} / \mathrm{mg}$ protein $/ 45 \mathrm{~min}$ over the first 8 days after plating.

\section{Discussion}

Several years ago we began a study of the interaction of ornithine decarboxylase activity and polyamines with epidermal cell growth [20]. As our work progressed, we found that to obtain enough homogenate supernatant with which to assay ODC 
Fig. 5. Metabolic pathways of ornithine. The conversion of arginine into agmatine and $\mathrm{CO}_{2}$ occurs only in microorganisms and plants

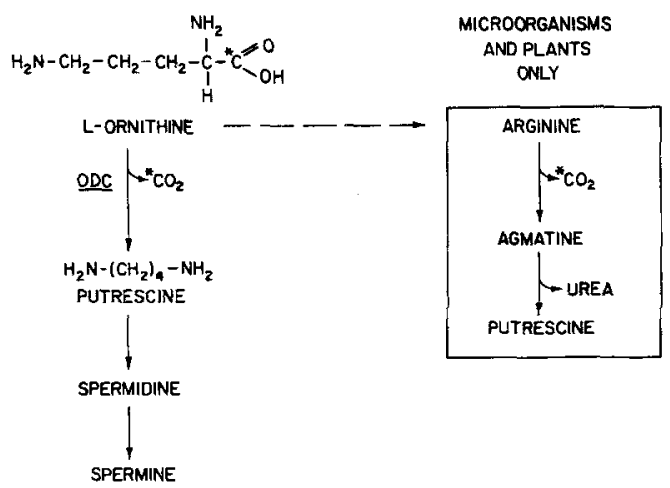

activity, we required $15-25 \times 10^{6}$ cells per time point, i.e., three to five $60-\mathrm{mm}$ petri dishes.

Even then, the values that we obtained for ODC activity were very low, often times giving raw cpm numbers equivalent to the blank values $(100-150 \mathrm{cpm})$. We overcame the time, cell number, and low-assay-sensitivity restraints and circumvented other problems due to the short half-life of this enzyme $[8,21]$ - the potentially variable and complex feedback control of ODC [7] and the existence of ODC in various growth-related states - by developing the whole living cell assay for ODC activity [20], which we are now completely describing in this report. Recently, similar results using the whole-cell assay of cell lines in culture have been reported [16].

The ODC activity of the intact cell cultures, as measured by the amount of ${ }^{14} \mathrm{CO}_{2}$ from $\mathrm{L}-\left[{ }^{14} \mathrm{C}\right]$ ornithine, ranged between 3,500 to 6,000 raw $\mathrm{cpm}$, the exact count depending on the number of cells on the coverslip and the age of the culture (Figs. 2, 4). These baseline values were obtained using $0.5-2.0 \times 10^{6}$ epidermal cells per coverslip. Correction for background, i.e., approximately $350 \mathrm{cpm}$, did not significantly effect the final value for ODC activity since assay background was only $5 \%-10 \%$ of the control raw cpm. This is not the case when the homogenate is used as the source of ODC. Often the background was equal to, or only slightly less than the control cpm, i.e., the blank value was $60 \%-100 \%$ of the control value; when the ODC activity of the cultures was stimulated [20] the background blank $(100 \mathrm{cpm})$ was often $20 \%-40 \%$ of the stimulated ODC activity number $(250-$ $500 \mathrm{cpm})$. It was very difficult for us to interpret this data since we often had no, or a very low, control ODC value with which to evaluate our stimulated ODC samples. Using the intact-cell assay, stimulated values were often $10,000-15,000 \mathrm{cpm}$ [20]; comparing control and experimental values with this ODC assay technique gave us more reliable information.

Since in the intact-cell assay the baseline (unstimulated) ODC activity was a constant and easily assayed value, it was possible to determine the effect of known inhibitors of ODC activity using the intact-cell assay technique. Three inhibitors of ODC activity in other cells were used. These were $\alpha$-methyl-ornithine, $\alpha$-hydrazino 
ornithine, and $\alpha$-difluoromethyl ornithine [1,6,10]. All three inhibitors decreased the ODC activity of intact, living epidermal cells between $40 \%-85 \%$ (Table 2 ). Actual assay of the polyamine levels of cultures treated with these metabolites for $6-7$ days indicated that the synthesis of putrescine was decreased $40 \%-50 \%$ in these cells by these inhibitors (Roseeuw, unpublished data).

The intact-cell assay gave greater values for ODC activity than those seen with the usual supernatant ODC assay (Table 1). This is not surprising when the unique labile nature of the ODC enzyme is considered. However, we used a number of criteria besides the decreased ${ }^{14} \mathrm{CO}_{2}$ release by classic ODC inhibitors (Table 2) to verify that we were indeed measuring only authentic ODC activity. We found that ODC activity was located primarily in the cell cytoplasm. When both the pellet and supernatant from cell homogenates were assayed for ODC activity, the decarboxylase activity was located primarily in the supernatant fraction (Table 1), although the pellet membranes were viable as shown by the presence of extensive Krebs cycle activity (Table 1). Thus, using whole cells containing intact cytoplasmic membrane structures does not contribute nonspecific decarboxylase activity to the assay reading. We used Dowex columns to identify the ornithine and ornithine metabolites in the assay mixture. The results showed that polyamines were being synthesized by the cells using the labeled ornithine as substrate (Fig. 3). Equally important is that there was an approximate $1: 1$ ratio between the ${ }^{14} \mathrm{CO}_{2}$ released and the ${ }^{14} \mathrm{C}$ polyamines present in the assay buffer, indicating that no decarboxylation of uniformally labeled ${ }^{14} \mathrm{C}$ ornithine was occurring through alternate pathways, i.e. the Krebs cycle. One other possible alternate pathway of ornithine decarboxylation was through the formation of agmatine (Fig. 5). In the epidermal cell, this would not occur since this pathway is present only in plants and microorganisms [18].

The results of our tests of this procedure, the decreased amount of ${ }^{14} \mathrm{CO}_{2}$ released from labeled ornithine caused by three ODC inhibitors and decreased putrescine synthesis in cells treated with these three inhibitors for $5-7$ days (Roseeuw, manuscript submitted for publication), are strong evidence that we were measuring authentic ODC activity. This conclusion is the same as that reported for a whole-cell assay of several cell lines in which the assay under anaerobic conditions was also used to verify this type of assay system.

The intact-cell ODC assay holds promise for future polyamine studies since this technique preserved and measured ODC activity in whole cells, thereby allowing all the fine tuning of the polyamine metabolite pathway to be expressed as the assay occurred. This data showed that the effect of changes in epidermal cell growth, and its relation to ODC activity and polyamine synthesis, can be better studied using this technique. In addition, the whole-cell assay technique will allow future study of the multiple ornithine metabolites and conjugates formed as a result of ODC activity in a totally manipulable in vitro system.

Acknowledgements. We would like to acknowledge the work done by Dr. Abdel-Monem without which this investigation would be incomplete. We would like to thank John J. Voorhees for stimulating discussions for this project, Lenore Rhodes for technical assistance, and Young G. Kim for providing the electron micrograph. This investigation was supported by Grants from NIAMDD AM 26009-02 and AM 07197-04 and by "het Fonds voor Geneeskundig Wetenschappelijk Onderzoek" and the "Vrije Universiteit Brussel", Brussels, Belgium. 


\section{References}

1. Abdel-Monem MM, Newton NE, Weeks CE (1974) Inhibitors of polyamine biosynthesis. 1. $\alpha$ methyl-(t)-ornithine, an inhibitor of ornithine decarboxylase. J Med Chem 17:447-451

2. Abdel-Monem MM, Ohno K, Newton NE, Weeks CE (1978) Thin-layer chromatography and highpressure liquid chromatography of dansyl polyamines. In: Campbell RA, Morris DR, Bartos D, Daves GD, Bartos F (eds) Advances in polyamine research, vol 2. Raven Press, New York, pp 37 49

3. Berger NA, Johnson ES (1976) DNA synthesis in permeabilized mouse L cells. Biochem Biophys Acta 425:1-17

4. Clark JL (1974) Specific induction of ornithine decarboxylase in 3T3 mouse fibroblasts by pituitary growth factors: Cell density-dependent biphasic response and alteration of half-life. Biochemistry $13: 4668-4674$

5. Goodwin P, Hamilton S, Fry L (1973) A comparison between DNA synthesis and mitosis in uninvolved and involved psoriatic epidermis and normal epidermis. Br J Dermatol 89:613-618

6. Harik SI, Pasternak GW, Snyder SH (1973) Putrescine: a sensitive assay and blockade of its synthesis by $\alpha$-hydrazino-ornithine. In: Russell DH (ed) Polyamines in normal and neoplastic growth. Raven Press, New York, pp 307-321

7. Heller JS, Fong WF, Canellakis ES (1976) Induction of a protein inhibitor to ornithine decarboxylase by the end products of its reaction. Proc Natl Acad Sci USA 73:1858-1862

8. Hogan BL, Murden S (1974) Effect of growth conditions on the activity of ornithine decarboxylase in cultured hepatoma cells. J Cell Physiol 83:345-352

9. Lichti U, Yuspa SH, Hennings H (1978) Ornithine and S-adenosylmethionine decarboxylases in mouse epidermal cell cultures treated with tumor promoters. In: Slaga TJ, Sivak A, Boutwell RK (eds) Mechanisms of tumor promotion and cocarcinogenesis. Raven Press, New York, pp $221-$ 232

10. Mamont PS, Duchesne MC, Grove J, Bey P (1978) Anti-proliferative properties of LD- $\alpha$ difluoromethyl ornithine in cultured cells. A consequence of the irreversible inhibition of ornithine decarboxylase. Biochem Biophys Res Commun 81:58-66

11. Marcelo CL, Kim YG, Kaine JL, Voorhees JJ (1978) Stratification, specialization and proliferation of primary keratinocyte cultures. J Cell Biol 79:356-370

12. Marks F, Fürstenberger G, Kownatzki E (1981) Prostaglandin E-mediated mitogenic stimulation of mouse epidermis in vivo by divalent cation ionophore A 23187 and by tumor promoter 12-0tetradecanoylphorbol-13-acetate. Cancer Res 41:696-702

13. Mitchell IL, Campbell HA, Carter DD (1976) Multiple ornithine decarboxylase forms in physarum polycephalum: Interconversion induced by cycloheximide. FEBS Letters $62: 33-37$

14. Murphy BJ, Brosnan ME (1976) Subcellular localization of ornithine decarboxylase in liver of control and growth-hormone-treated rats. Biochem J 157:33 - 39

15. O'Brien TG, Simsiman RC, Boutwell RK (1975) Induction of polyamine-biosynthetic enzymes in mouse epidermis and their specificity for tumor promotion. Cancer Res 35:2426-2433

16. Patterson MK, Maxwell MD (1980) In situ assay for ornithine decarboxylase in tissue culture. Anal Biochem 104:452-456

17. Pegg AE, Williams-Ashman HG (1968) Biosynthesis of putrescine in the prostate gland of the rat Biochem I 108:533-539

18. Pegg AE, McGill S (1979) Decarboxylation of ornithine and lysine in rat tissues. Biochem Biophys Acta $56: 416-427$

19. Raina A, Jänne J (1975) Physiology of the natural polyamines, putrescine, spermidine and spermine. Med Biol 53:121-147

20. Roseeuw DI, Marcelo CL, Duell EA, Voorhees JJ (1979) Cyclic AMP stimulates epidermal cell ornithine decarboxylase activity and epidermal cell proliferation. J Invest Dermatol 72:272

21. Russell DH, Snyder SH (1969) Amine synthesis in regenerating rat liver: Extremely rapid turnover of ornithine decarboxylase. Mol Pharmacol 5:253-262

22. Russell DH, Combest WL, Duell EA, Stawiski MA, Anderson TF, Voorhees JJ (1978) Glucocorticoid inhibits elevated polyamine biosynthesis in psoriasis. J Invest Dermatol 71:177181

23. Vandemark FL, Schmidt IJ, Slaven W (1978) Determination of polyamines by liquid chromatography and pre-column labelling for fluorescence detection. J Chromatogr Sci 16:465 
24. Verma AK, Rice HM, Boutwell RK (1977) Prostaglandins and skin tumor promotion: Inhibition of tumor promoter-induced ornithine decarboxylase activity in epidermis by inhibitors of prostaglandin synthesis. Biochem Biophys Res Commun 79:1160-1166

25. Verma AK, Ashendel CL, Boutwell RK (1980) Inhibition by prostaglandin synthesis inhibitors of the induction of epidermal ornithine decarboxylase activity, the accumulation of prostaglandins, and tumor promotion caused by 12-0-tetradecanoylphorbol-13-acetate. Cancer Res 40:308-315

26. Weinstein GD, Frost P (1968) Abnormal cell proliferation in psoriasis. J Ivest Dermatol 50:254259

27. Yuspa SH, Lichti U, Ben T, Patterson E, Hennings H, Slaga TJ, Colburn N, Kelsey W (1976) Phorbol esters stimulate DNA synthesis and ornithine decarboxylase activity in mouse epidermal cell cultures. Nature 262:402-404

Received May 25, 1981 